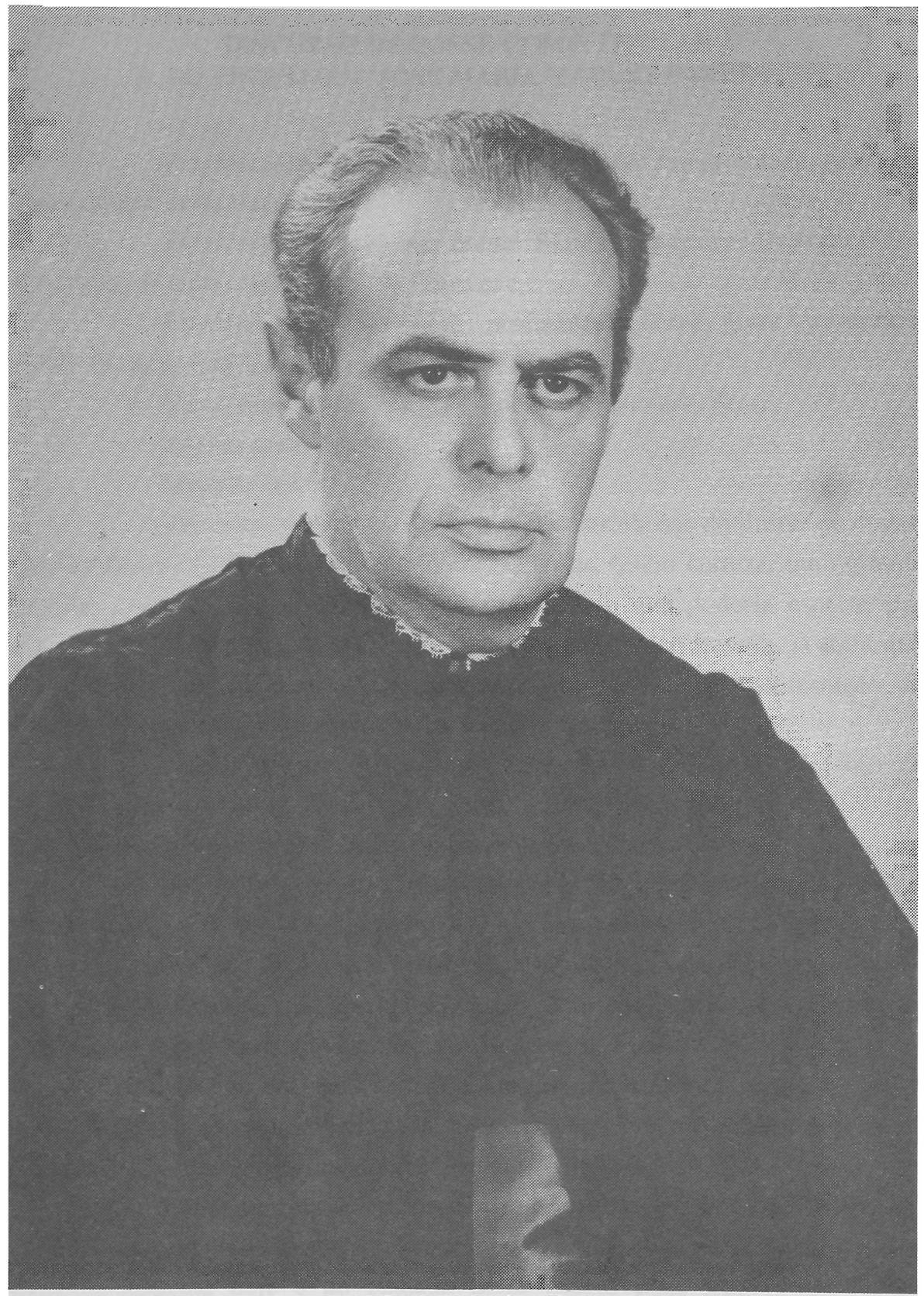

José Maria Marlet Pareta 


\section{DISCURSO DE POSSE COMO TITULAR DO PROFESSOR JOSÉ MARIA MARLET PARETA}

Excelentíssimo professor doutor Antonio Junqueira de Azevedo, digno diretor desta Faculdade,

Excelentíssimo professor doutor Manoel Gonçalves Ferreira Filho, presidente do Conselho Federal de Educação,

Excelentíssimos senhores professores desta Casa e demais membros da egrégia Congregação,

Caros alunos, futuro deste grande país chamado Brasil,

Minhas senhoras,

Meus senhores,

Muito me sensibilizaram as palavras carinhosas do ilustre professor doutor Manoel Gonçalves Ferreira Filho. Há nelas, tenho certeza, uma grande dose de generosidade, ditada mais pela amizade do que poderia esperar por meus eventuais méritos. Lacordaire, o brilhante acadêmico francês, já dizia que "a bondade, mais do que tudo, desarma os homens" Esta manifestação de bondade desarma também a mim, neste instante de emoção.

Atingir o ápice da carreira universitária é, por si, um fato de significativa importância na vida de quem escolhe o caminho do magistério, dedicada integralmente ao trabalho do ensino e da pesquisa.

Isto só foi possível por ter contado diária e ininterruptamente com a compreensão e apoio de minha família, em especial de minha esposa, companheira e amiga de todas as horas, a quem presto, neste momento, minhas mais sinceras homenagens, por ter sabido suportar com exemplar paciência os sacrifícios pessoais que, muito a contragosto, lhe ocasionei.

Adquire uma importância e uma responsabilidade maiores e ainda mais significativas em se tratando do coroamento dessa carreira, numa instituição tão prestigiosa, quanto esta Faculdade de Direito.

Já não se trata de integrar um quadro seleto de docentes devotados e reconhecidamente respeitáveis. Trata-se do privilégio de fazer parte de uma minoria, formada hoje e no passado pelos nomes mais ilustres do campo universitário deste país. De um núcleo de valores intelectuais que sempre projetou a melhor imagem da universidade brasileira em todo o mundo. 
Ademais, cresce imensamente a responsabilidade de quem ingressa neste núcleo seleto, pelo mesmo caminho que trilharam homens do porte de Amâncio de Carvalho, de Alcântara Machado, de Antonio Ferreira de Almeida Jr., de João Baptista de Oliveira e Costa Jr., de Odon Ramos Maranhão.

A grandeza destes conceituados mestres transforma em desafio o que seria apenas um privilégio. Um desafio para o qual a maior coragem não assegura o êxito e muito menos a pretensão de igualar-se a estes notáveis antecessores.

Chego a este ponto de minha carreira por força dos estímulos do professor Odon Ramos Maranhão, que me joga nos ombros a responsabilidade, ou antes, o desafio de sucedê-lo. Proeza para a qual somente me aventuro por saber que ele me transfere também, como legado de valor incalculável, uma equipe de abnegados, competentes e leais colaboradores, que constitui a base, quantitativamente reduzida, mas de uma qualidade grandiosa, do Departamento de Medicina Forense.

Só lamento que ele próprio, o professor Odon Ramos Maranhão, por força de uma aposentadoria, a nosso ver, precoce, não esteja mais no comando dessa equipe. A propósito, faço minhas, as palavras do professor Costa Jr., no seu discurso de posse nesta mesma cadeira, quando sucedeu ao professor Almeida Jr.. Disse ele: "Com toda sinceridade, e apesar de ter sido um interessado direto e candidato confesso à cátedra de Medicina Legal, posso assegurar que senti a aposentadoria do professor Almeida Jr. como poucos a poderiam ter sentido". Eu também sinto a aposentadoria do professor Odon Ramos Maranhão como poucos poderiam ter sentido.

Fui atraído para o fantástico e apaixonante mundo da Medicina Legal e iniciei nos seus mistérios pelas mãos seguras e firmes do saudoso professor Armando Canger Rodrigues. Dele não posso esquecer, neste momento, já que foi o responsável pela mudança de rota do meu destino profissional.

Foi ele quem me abriu as portas e mostrou o caminho que, por mim mesmo, não havia descoberto até aquele momento. Graças a ele, me foi possível conciliar o meu desejo íntimo, minha satisfação pessoal, e até a minha vocação, com a atividade que me abriu promissora perspectiva de 
desenvolvimento profissional. Posso assim dizer, com convicção, que faço o que gosto e que gosto do que faço.

Que a vida me seja generosa e complacente, para poder continuar nesta linha traçada para o meu destino profissional, dentro desta Faculdade de tão venerandas tradições, algumas das mais caras assentadas sobre o exemplo ímpar de um Julio Frank.

Que o tempo e o futuro colaborem comigo até para, mais uma vez, comprovar o que disse, há tempos, à eminente professora doutora Ada Pellegrini Grinover, a quem tanto deve o Departamento de Medicina Forense. Numa sua colocação, pejada de sabedoria, disse ela que "uma instituição somente sobrevive, quando os que a integram se identificam com os principios de sua existência e com as suas finalidades últimas"

Este tem sido o segredo destas Arcadas; esta tem sido a base de sustentação do seu prestígio e de sua importância. Qual seja, a identificação de todos os componentes dos seus corpos docente e discente com os princípios de sua existência e com as suas finalidades últimas.

De minha parte, posso assegurar que também me identifico com estes princípios e com estas finalidades. Por isso, sinto-me prazerosamente à vontade e perfeitamente solidário quando me integro, em definitivo, a esta egrégia e venerável Congregação.

Minhas senhoras,

Meus senhores,

Estas Arcadas têm uma particularidade muito especial que a diferencia de tudo o mais: elas abrigam uma tradição que se renova a cada instante, que se inova permanentemente, sem perder o seu princípio e sem se desviar do seu futuro.

Num refazendo, como se diz da práxis poética, como se fora a flor utópica a gerar dentro de si uma nova flor, num reproduzir incessante e ininterrupto de novas flores.

Ao abrigo destas Arcadas, há uma emanação permanente de idéias inovadoras que se desabrocham em infinitas outras idéias, permitindo assim manter todo um princípio inovador, modernizante e precursor de renovações.

Por isso, esta Faculdade não precisa jamais apagar o seu passado de tradições para ingressar nas alvoradas inovadoras do futuro. Esta Faculdade 
não se moderniza e não precisa modernizar-se, como fazem outras instituições, quando o mofo da acomodação a isto as impele, pois é sempre moderna.

Esta Faculdade mantém-se sempre moderna, porque ela comanda a modernização; ela é a precursora das inovações e das renovações. Como a flor que renasce incessantemente de dentro de si.

Um exemplo cristalino é o próprio Departamento que hoje assumo como titular. Por força deste processo renovador, esta Faculdade teve a sensibilidade, no momento oportuno, de, numa iniciativa pioneira, desvincular a Medicina Forense, própria do mundo jurídico, da Medicina Legal, própria do mundo médico.

Com efeito, cabe à Medicina Legal a execução das perícias médicolegais. Cabe à Medicina Forense, dentro dos parâmetros inerentes ao campo jurídico, capacitar o bacharel a interpretar e utilizar os laudos produzidos pela Medicina Legal, compatibilizando-os com os avanços e com as mudanças conceituais do mundo jurídico e jurisprudencial.

Lamentavelmente, em nosso país, o progresso da Medicina Legal não tem acompanhado os avanços da modernidade, como já o faz a Medicina Forense. Não penetrou ainda a Medicina Legal nos campos novos, abertos pela evolução tecnológica, pelo desenvolvimento social e pelos problemas supervenientes da sociedade contemporânea.

Ainda persiste, a propósito, um atraso considerável no campo da drogadição. Ainda se mutilam os cadáveres, em arcaicas autópsias, quando a tecnologia avançada da tomografía computadorizada já permite resultados periciais tão exatos e confiáveis, sem fazer necessariamente do perito um extirpador. $\mathrm{E}$ ainda, sem ferir o sentimento natural das pessoas, às quais repugna ver um ente querido passar pelo esquartejamento de uma perícia à moda antiga.

Seguindo a tradição renovadora desta Faculdade, a Medicina Forense, ministrada sob estas Arcadas, mantém o pioneirismo na aplicação das conquistas não só jurídicas, mas também dos avanços tecnológicos. Assim, o Departamento de Medicina Forense vem transmitindo aos alunos os conhecimentos científicos mais evoluídos no campo da Genética, como, por exemplo, os conhecimentos sobre o DNA.

Esta molécula básica, que compõe o núcleo da célula e que contém toda a carga genética do ser humano, está para a Criminologia, em termos de 
identificação, como a impressão digital esteve no fim do século passado. Apenas isto já permite vislumbrar sua extraordinária importância no campo do Direito Penal.

Mas não é neste que se esgota sua potencialidade. Também no campo cível sua relevância é extrema: Na comprovação jurídica da paternidade, as provas que se produziam até recentemente eram obtidas por exclusão. Portanto, de confiabilidade discutível. A utilização do DNA produz provas de afirmação, de absoluta segurança. É o avanço tecnológico contribuindo para o avanço da ciência jurídica.

Para materializar este avanço, valendo-se de convênio existente entre esta Faculdade e a Academia de Polícia de São Paulo, o Departamento de Medicina Forense está montando um laboratório de DNA. Através dele, os futuros bacharéis sairão destas Arcadas com mais una ferramenta de trabalho de fundamental importância.

No campo doutrinário, o entendimento herdado dos ilustres antecessores faz com que o Departamento de Medicina Forense, ao estudar a Criminologia, não se limite à simples repetição dos conceitos alienígenas de criminologistas de primeira linha e de renome internacional, por mais importantes que sejam. Na maioria das vezes, esses conceitos são fruto das condições sociais e biológicas locais, obviamente diferentes das nossas.

Cabe, pois, à Criminologia brasileira estudar as condições e as causas, quer antropológicas, quer sociais, de nossa criminalidade, utilizando para isso todo o potencial existente e as amplas possibilidades de pesquisa científica, oferecidas pelas condições brasileiras.

Fruto dessa linha de pensamento, em perfeita harmonia de propósitos entre os Departamentos de Direito Penal e de Medicina Forense, foi o nascimento do Instituto Manoel Pedro Pimentel Centro de Estudos Penais e Criminológicos.

Esta formidável capacidade de refazer e inovar de nossa Faculdade é que me anima ainda mais, ao transpor este novo horizonte de minha carreira no magistério universitário, dentro das venerandas Arcadas.

Espero que as minhas limitações não sejam tão perversas e tão resistentes a ponto de dificultar a trajetória deste Departamento e de esmaecer o 
brilho de sua tradição, no caminho da modernidade e do progresso, que as perspectivas de um mundo em transformação abrem diante de nós.

Espero, ainda, que a força do meu ânimo e o ímpeto do meu desejo sejam suficientemente poderosos para superar todas as dificuldades e todos os obstáculos, a fim de que a tradição e o brilho desta Faculdade continuem imorredouros, de geração em geração e por todo o sempre.

Assim, o destino me ajude.

Muito obrigado. 